\title{
Role of SARS-CoV-2 neurotropism and neuroinvasion in COVID-19 patients disease severity
}

\author{
Israel Grijalva-Otero* \\ Instituto Mexicano del Seguro Social, Centro Médico Nacional Siglo XXI, Specialty Hospital, Mexico City, Mexico
}

\begin{abstract}
The disease caused by the new SARS-CoV-2 coronavirus (COVID-19) spread rapidly from China to the entire world. Approximately one third of SARS-CoV-2-infected patients have neurological disorders, especially those classified as severe cases and that require mechanical ventilation. On the other hand, almost nine out of 10 patients admitted to an Intensive Care Unit could not breathe spontaneously, thus requiring invasive and non-invasive ventilatory support. So far, whether early neurological disorders such as hyposmia or anosmia, dysgeusia or ageusia, headache and vertigo are significant in the progression to the severe form of the disease or whether they are related to entry to the central nervous system via peripheral nerves has not been determined. Considering the great similarity between SARS-COV and SARS-CoV-2, and that the severity of the condition that leads to death cannot be explained solely by lung involvement, it is important to determine whether SARS-CoV-2 potential invasion to the central nervous system is partially responsible for the severe respiratory component observed in patients with COVID-19.
\end{abstract}

KEY WORDS: Central respiratory failure. Central respiratory control. Peripheral nerve viral uptake. Trans-synaptic invasion.

\section{Papel del neurotropismo y neuroinvasión de SARS-CoV-2 en la gravedad de los pacientes con COVID-19}

\section{Resumen}

La enfermedad (COVID-19) producida por el nuevo coronavirus SARS-CoV-2 se extendió rápidamente desde China a todo el mundo. Aproximadamente una tercera parte de los pacientes infectados de SARS-CoV-2 presenta alteraciones neurológicas, con mayor frecuencia los clasificados como graves que requirieron ventilación mecánica. Por otro lado, casi nueve de cada 10 pacientes admitidos en una unidad de cuidados intensivos no podían respirar espontáneamente, por lo que ameritaron apoyo ventilatorio invasivo y no invasivo. Hasta el momento no se ha determinado si las alteraciones neurológicas tempranas como la hiposmia o anosmia, disgeusia o ageusia, cefalea y vértigo son significativas en la progresión a la forma grave de la enfermedad y se relacionan con la entrada al sistema nervioso central a través de los nervios periféricos. Considerando la gran similitud entre SARS-CoV y SARS-CoV-2 y que la severidad del cuadro que conduce a la muerte no puede ser explicado únicamente por la afección pulmonar, es importante determinar si la invasión potencial del SARS-CoV-2 al sistema nervioso central es parcialmente responsable del componente respiratorio severo que presentan los pacientes con COVID-19.

PALABRAS CLAVE: Insuficiencia respiratoria central. Control central de la respiración. Absorción viral por nervios periféricos. Invasión transináptica. 


\section{Introduction}

In late December 2019, in Wuhan, China, groups of patients presenting with atypical pneumonia of unknown origin were reported. Detailed study of three patients' bronchial lavage -which included whole genome sequencing, polymerase chain reaction (PCR) testing and culture- showed the presence of a new virus, which was initially named $2019-\mathrm{nCoV},{ }^{1}$ belonging to the betacoronavirus genus that includes SARSCoV, bat SARS-like CoV and others discovered in humans, bats and other wild animals. ${ }^{2}$ The disease caused by this new coronavirus (coronavirus disease [COVID-19]) spread quickly throughout the rest of the world.

Apparently, 2019-nCoV pathogenesis (currently called SARS-CoV-2) is similar to that of SARS-CoV and MERS-CoV, ${ }^{3}$ with the same mechanism of entry into the host cell, mediated by angiotensin-converting enzyme 2 (ACE2) receptor. ${ }^{4}$

Common symptoms of COVID-19 at disease onset were fever, fatigue, and dry cough, 5,6 but more than half of infected patients complained about dyspnea, and $29 \%$ developed acute respiratory distress syndrome. ${ }^{6}$

From $26 \%$ to $32 \%$ of hospitalized cases required admission to an intensive care unit5, ${ }^{5,6}$ and the most common complication in this group was acute respiratory distress syndrome, in $29 \%$ of cases $(n=12 / 41) .{ }^{6}$ However, 32 patients ( $89 \%$ ) admitted to the intensive care unit were unable to spontaneously breathe, and thus they required invasive and non-invasive ventilatory support. ${ }^{5}$

\section{COVID-I9 neurological involvement}

Numerous patients with COVID-19 have presented with neurological alterations. Mao et al. identified nonspecific (headache, impaired state of consciousness, vertigo or seizures) and specific neurological manifestations (loss of the sense of smell or taste, musculoskeletal disorders and cerebral infarction) in $36.4 \%$ of 217 cases; especially, smell or taste disorders and musculoskeletal alterations occurred in the early phase of clinical course. ${ }^{7}$ These researchers also recorded a higher frequency of neurological symptoms in patients who required mechanical ventilation classified as being severely ill $(45.5 \%)$ in comparison with those in not serious conditions $(30.2 \%)$; in addition, seriously ill patients showed the most evident neurological data, including impaired consciousness, cerebral infarction and seizures. ${ }^{7}$ Other neurological disorders such as meningoencephalitis $^{8}$ and Guillain-Barre syndrome ${ }^{9}$ have also been associated with COVID-19.

\section{Probable routes of dissemination to the central nervous system}

The presence of neurological disorders in approximately one third of patients infected with SARSCoV-2 forces to try to identify the access routes to the peripheral nervous system and to the central nervous system (CNS). Being a disease that affects the entire "body economy", it is to be expected that multiple organs are altered, including the peripheral nerves; however, damage to the CNS is only possible if the blood-brain barrier (BBB) is ruptured or if the virus enters through areas where the BBB does not exist. The hematogenous route, with its variants, is used by other pathogens, either by inflammation of endothelial cells with BBB secondary rupture, through the choroid plexuses and periventricular areas, or by severe systemic inflammation that also induces BBB rupture. ${ }^{10}$ Another possibility is the transethmoidal route, through which pathogens travel around the nerve bundles that pass through the cribriform plate, and then disseminate through the Virchow-Robin spaces around the arteries and veins that penetrate the brain.11

SARS-CoV-2 neurotropism suspicion is based on the symptoms presented by patients with COVID-19: smell and taste alterations ${ }^{7,12}$ and specific conditions such as Guillain-Barre syndrome indicate peripheral nervous system involvement; ${ }^{9}$ vertigo, headache, impaired consciousness, seizures, or specific conditions such as cerebral infarctions and hemorrhages, as well as meningoencephalitis, reveal CNS compromise.,8

Most betacoronaviruses, including SARS-CoV ${ }^{13}$ and MERS-CoV,${ }^{14}$ have been documented to be characterized by neurotropism, which allows them to affect the nervous system, i.e., neuroinvasion. However, CNS infection cannot be explained solely by ACE2 (in SARS-CoV) ${ }^{4,15}$ or dipeptidyl peptidase 4 mediation (in MERS-CoV), ${ }^{16}$ which constitute the vehicles to enter the host cells, since their expression in the brain is very low under normal conditions. ${ }^{15-17}$ As a matter of fact, ACE2 was not identified in brain tissue but in brain vessels endothelium and smooth muscle. ${ }^{15}$

Given that SARS-CoV-2 is very similar to SARSCoV, CNS involvement has been thought to likely 
follow the same pathways. Viral particles were observed almost exclusively in neurons in specimens from patients infected with SARS-CoV in 2002 and 2003. ${ }^{18}$ Subsequently, in intranasally-infected transgenic mice, MERS-CoV and SARS-CoV were found to be able to enter the brain through the olfactory nerves. ${ }^{14,19}$ SARS-CoV rapidly disseminated to brain structures that connect to the olfactory pathway such as the piriform and infralimbic cortex, some basal ganglia and the midbrain, as well as the thalamus, hypothalamus and amygdala. Other brain sites unrelated to the olfactory pathway such as the dorsal vagal complex, the ambiguous nucleus, and the hypoglossal nucleus were also affected, suggesting infection by oral absorption. ${ }^{19}$

In mice intranasally infected with MERS-CoV particle inocula, viral particles were only detected in the brain, indicating that CNS infection was more important in infected mice mortality. ${ }^{14}$ Furthermore, infection of the medulla oblongata cardiorespiratory center occurred even when the mice received low doses of SARS-CoV, which could also contribute to the animals' death. ${ }^{19}$ The relationship of mortality with brain infection reported by Li et al. and Netland et al. in their experimental models, suggests that CNS infection was more important than lung infection. ${ }^{14,19}$

The presence of coronavirus in the CNS of humans has also been demonstrated. In autopsy samples of eight people who had severe acute respiratory syndrome, SARS-CoV genomic sequences were found by immunohistochemistry, electron microscopy, and reverse transcriptase PCR (RT-PCR), confined to neurons of the hypothalamus and cortex, as well as edema and neuronal degeneration in six of the eight cases. ${ }^{20}$ In another case related to the same virus, pathological examination showed neuronal necrosis and glial cell hyperplasia. ${ }^{21}$ Lau et al. described a patient with seizures who was positive for SARS-CoV in cerebrospinal fluid by PCR. ${ }^{22}$ Recently, by RT-PCR, SARS-CoV-2 was found in cerebrospinal fluid of a patient with meningitis-encephalitis. ${ }^{8}$

\section{Neurological and respiratory data in patients with coronavirus}

Although severely ill COVID-19 patients showed the most evident neurological data (impaired consciousness, cerebral infarction, and seizures), and neurological symptoms were more common in those who also required mechanical ventilation, ${ }^{7}$ whether specific (smell, taste, and musculoskeletal alterations) and nonspecific neurological manifestations (headache and vertigo) play any role in the progression to the severe form of the disease has not been determined.

On the other hand, more than half the patients reported by Huang $C$ et al. complained of dyspnea and almost one third of them developed acute respiratory distress syndrome. ${ }^{6}$ Furthermore, $89 \%$ of patients admitted to an intensive care unit reported by Wang et al. were unable to breathe spontaneously, which warranted invasive and non-invasive ventilatory support. ${ }^{5}$ Finally, empirical data collected in Mexico indicate that some patients without dyspnea showed oxygen desaturation, as determined by peripheral oximetry, and thus they were hospitalized and eventually intubated (verbal communication). Whether the respiratory failure that warranted assisted ventilation in these patients was type 1 or 2 has thus far not been reported; the former is generated by a pneumonia that typically develops hypoxia, hypocapnia and increased respiratory rate, with patients being able to breathe spontaneously, but with greater difficulty; in the latter, cerebral alteration generates respiratory failure, which usually manifests itself with lower respiratory rate, hypoxia and hypercapnia. ${ }^{23}$ In view of the above, it has not been possible to define whether the respiratory problem was central or peripheral, or of onset or predominance at one or another level.

\section{Neuroinvasion and neurotropism}

The seizures, heart attacks and cerebral hemorrhages that severely ill COVID-19 patients present with, including meningoencephalitis in the aforementioned case, ${ }^{8}$ suggest that CNS involvement might be generalized and not focalized, similar to that generated in other organs of the body, which could be attributed to hematogenous invasion, the most probable mechanisms of which could be the following:

a) Brain vessels endothelial and muscle cells inflammation with secondary BBB rupture, since at the cerebral level only endothelial and smooth muscle cells express ACE2. ${ }^{15}$

b) Severe systemic inflammation or hyper-inflammation, characterized by an increase of different cytokines such as tumor necrosis factor alpha, interferon gamma, different stimulatory or 
chemoattractant factors and interleukins, among which IL- $6^{24-26}$ stands out, which might also induce BBB rupture.

On the other hand, considering patient symptoms and that coronaviruses such as SARS-CoV and MERS-CoV, and most likely SARS-CoV-2, have neurotropism, which affects peripheral nerves, they could enter the CNS through them and transneuronally disseminate therein. ${ }^{14,19}$ Given that almost nine out of 10 patients in Europe reported olfactory and gustatory dysfunction, ${ }^{12}$ the olfactory and glossopharyngeal nerves could be the gateway to the CNS. Olfactory and oral absorption of viruses in humans and their transneuronal dissemination could affect the dorsal vagal complex, which includes the nucleus of the solitary tract and the ambiguous nucleus, which are important structures in the respiratory cycle. ${ }^{19}$ Viral absorption through mechanoreceptors and chemoreceptors of the lung and respiratory tract can also affect the nucleus of the solitary tract and the ambiguous nucleus. ${ }^{27,28}$ This would explain type 2 respiratory failure, which is likely to influence on the severity of the respiratory problem and secondary mortality. Empirical observations indicate that, apparently, severe pneumonia on imaging does not correspond to a moderate respiratory clinical condition, and neither to a shorter time between intubation and mechanically assisted ventilation and death.

\section{Conclusions}

The severity of the clinical presentation that leads to death cannot be solely explained by lung involvement in patients with COVID-19. Given the similarity between SARS-CoV and SARS-CoV-2, it is important to find out if the potential CNS invasion by SARS-CoV-2 is partially responsible, for which it will be necessary to demonstrate the presence and topographic distribution of the virus in brain tissue by post mortem histopathological examination, as well as its detection in cerebrospinal fluid by RTPCR and culture in patients with neurological complications by COVID-19. In uncomplicated patients, but with neurological symptoms, biomarkers of neuronal, glial, and blood-brain barrier damage associated with COVID-I9 diagnosis should be tracked in order to detect early CNS invasion and determine the role it plays in patient disease severity and mortality.

\section{Conflict of interests}

The author declares that he has no conflicts of interest.

\section{Funding}

The author received no funding to carry out this article.

\section{Ethical disclosure}

Protection of people and animals. The author declares that no experiments were performed on humans or animals for this investigation.

Confidentiality of data. The author declares that no patient data appear in this article.

Right to privacy and informed consent. The author declares that no patient data appear in this article.

\section{References}

1. Zhu N, Zhang D, Wang W, Li X, Yang B, Song J, et al. A novel coronavirus from patients with pneumonia in China, 2019. N Engl J Med. 2020:382:727-733

2. Tan W, Zhao X, Ma X, Wang W, Niur P, Xu W, et al. A novel coronavirus genome identified in a cluster of pneumonia cases-Wuhan, China 2019-2020. China CDC Weekly. 2020;2:61-62.

3. Song Z, Xu Y, Bao L, Zhang L, Yu P, Qu Y, et al. From SARS to MERS, thrusting coronaviruses into the spotlight. Viruses. 2019;11:59.

4. Wan Y, Shang J, Graham R, Baric RS, Li F. Receptor recognition by novel coronavirus from Wuhan: An analysis based on decadellong structural studies of SARS coronavirus. J Virol. 2020;94:e00127-20.

5. Wang D, Hu B, Hu C, Zhu F, Liu X, Zhang J, et al. Clinical characteristics of 138 hospitalized patients with 2019 novel coronavirusロinfected pneumonia in Wuhan, China. JAMA. 2020;323:1061-1069.

6. Huang C, Wang Y, Li X, Ren L, Zhao J, Hu Y, et al. Clinical features of patients infected with 2019 novel coronavirus in Wuhan, China. Lancet. 2020;395:497-506

7. Mao L, Jin H, Wang M, Hu Y, Chen S, He Q, et al. Neurologic manifestations of hospitalized patients with coronavirus disease 2019 in Wuhan, China. JAMA Neurol. 2020;77:1-9.

8. Moriguchi T, Harii N, Goto J, Harada D, Sugawara H, Takamino J, et al. A first case of meningitis/encephalitis associated with SARS-coronavirus-2. Int J Infect Dis. 2020:94:55-58.

9. Toscano G, Palmerini F, Ravaglia S, Ruiz L, Invernizzi P, Cuzzoni MG, et al. Guillain-Barré syndrome associated with SARS-CoV-2. N Engl J Med. 2020:NEJMc2009191.

10. Swanson PA, McGavern DB. Viral diseases of the central nervous system. Curr Opin Virol. 2015;11:44-54.

11. Wehn SM, Heinz ER, Burger PC, Boyko OB. Dilated Virchow-Robin spaces in cryptococcal meningitis associated with AIDS: CT and MR findings. J Comput Assist Tomogr. 1989;13:756-762.

12. Lechien JR, Chiesa-Estomba CM, de Siati DR, Horoi M, le Bon SD, Rodríguez A, et al. Olfactory and gustatory dysfunctions as a clinical presentation of mild-to-moderate forms of the coronavirus disease (COVID-19): A multicenter European study. Eur Arch Otorhinolaryngol. 2020:1-11.

13. Glass WG, Subbarao K, Murphy B, Murphy PM. Mechanisms of host defense following severe acute respiratory syndromencoronavirus (SARS-CoV) pulmonary infection of mice. J Immunol. 2004:173:4030п4039.

14. Li K, WohlfordaLenane C, Perlman S, Zhao J, Jewell AK, Reznikov LR, et al. Middle East respiratory syndrome coronavirus causes multiple organ damage and lethal disease in mice transgenic for human dipeptidyl peptidase 4. J Infect Dis. 2016;213:712ロ722. 
15. Hamming I, Timens W, Bulthuis ML, Lely AT, Navis G, van Goor H. Tissue distribution of ACE2 protein, the functional receptor for SARS coronavirus. A first step in understanding SARS pathogenesis. J Pathol. 2004;203:6310637.

16. Boonacker $E$, Van Noorden CJ. The multifunctional or moonlighting protein CD26/DPPIV. Eur J Cell Biol. 2003:82:53ロ73.

17. Harmer D, Gilbert M, Borman R, Clark KL. Quantitative mRNA expression profiling of ACE 2, a novel homologue of angiotensin converting enzyme. FEBS Lett. 2002;532:107-110.

18. Ding $Y$, He L, Zhang Q, Huang Z, Che X, Hou J, Wang $\mathrm{H}$, et al. Organ distribution of severe acute respiratory syndrome (SARS) associated coronavirus (SARSロCoV) in SARS patients: Implications for pathogenesis and virus transmission pathways. J Pathol. 2004;203:622־630.

19. Netland J, Meyerholz DK, Moore S, Cassell M, Perlman S. Severe acute respiratory syndrome coronavirus infection causes neuronal death in the absence of encephalitis in mice transgenic for human ACE2. J Virol. 2008:82:7264ロ7275.

20. Gu J, Gong E, Zhang B, Zheng J, Gao Z, Zhong Y, et al. Multiple organ infection and the pathogenesis of SARS. J Exp Med. 2005;202:415-424.

21. Xu J, Zhong S, Liu J, Li L, Li Y, Wu X, et al. Detection of severe acute respiratory syndrome coronavirus in the brain: potential role of the chemokine Mig in pathogenesis. Clin Infect Dis. 2005;41:1089-1096.
22. Lau KK, Yu WC, Chu CM, Lau ST, Sheng B, Yuen KY. Possible central nervous system infection by SARS coronavirus. Emerg Infect Dis. 2004;10:342-344.

23. Turtle L. Respiratory failure alone does not suggest central nervous invasion by SARS-CoV-2. J Med Virol. 2020;92:705-706.

24. Fu Y, Cheng Y, Wu Y. Understanding SARS-CoV-2-mediated inflammatory responses: From mechanisms to potential therapeutic tools. Virol Sin. 2020;1-6.

25. Ruan Q, Yang K, Wang W, Jiang L, Song J. Clinical predictors of mortality due to COVID-19 based on an analysis of data of 150 patients from Wuhan, China. Intensive Care Med. 2020;46:846-848.

26. Mehta P, McAuley DF, Brown M, Sanchez E, Tattersall RS, Manson JJ. COVID-19: consider cytokine storm syndromes and immunosuppression. Lancet. 2020;395:1033-1034.

27. Matsuda $\mathrm{K}$, Park $\mathrm{CH}$, Sunden $\mathrm{Y}$, Kimura T, Ochiai $\mathrm{K}$, Kida $\mathrm{H}$, et al. The vagus nerve is one route of transneural invasion for intranasally inoculated influenza a virus in mice. Vet Pathol. 2004;41:1010107.

28. Li YC, Bai WZ, Hashikawa T. The neuroinvasive potential of SARSCoV-2 may play a role in the respiratory failure of COVID-19 patients. J Med Virol. 2020;92:552-555. 